\title{
Short communication: Characterization of molasses chemical composition
}

\author{
A. Palmonari, ${ }^{1 *} \dagger \odot$ D. Cavallini, ${ }^{1}$ C. J. Sniffen, ${ }^{2} \odot$ L. Fernandes,${ }^{3}$ P. Holder,${ }^{3} \odot$ L. Fagioli, ${ }^{4}$ I. Fusaro, ${ }^{5} \odot$ G. Biagi, ${ }^{1}$ \\ A. Formigoni, ${ }^{1}$ (D) and L. Mammi ${ }^{1}$ (D) \\ ${ }^{1}$ DIMEVET, Dipartimento di Scienze Mediche Veterinarie, Università di Bologna, 40064 Ozzano Emilia, Italy \\ ${ }^{2}$ Fencrest LLC, Holderness, NH 03245 \\ ${ }^{3}$ ED\&F Man Liquid Products, London, SE1 9SG, UK \\ ${ }^{4}$ Studio Associato Campi-Fagioli, 44123 Ferrara, Italy \\ ${ }^{5}$ Facoltà di Medicina Veterinaria, Università di Teramo, 64100 Teramo, Italy
}

\section{ABSTRACT}

Beet and cane molasses are produced worldwide as a by-product of sugar extraction and are widely used in animal nutrition. Due to their composition, they are fed to ruminants as an energy source. However, molasses has not been properly characterized in the literature; its description has been limited to the type (sugarcane or beet) or to the amount of dry matter (DM), total or water-soluble sugars, crude protein, and ash. Our objective was to better characterize the composition of cane and beet molasses, examine possible differences, and obtain a proper definition of such feeds. For this purpose, 16 cane and 16 beet molasses samples were sourced worldwide and analyzed for chemical composition. The chemical analysis used in this trial characterized 97.4 and $98.3 \%$ of the compounds in the DM of cane and beet molasses, respectively. Cane molasses contained less DM compared with beet molasses $(76.8 \pm 1.02$ vs. $78.3 \pm 1.61 \%)$ as well as crude protein content $(6.7 \pm$ 1.8 vs. $13.5 \pm 1.4 \%$ of $\mathrm{DM}$ ), with a minimum value of $2.2 \%$ of DM in cane molasses and a maximum of $15.6 \%$ of DM in beet molasses. The amount of sucrose differed between beet and cane molasses $(60.9 \pm 4.4$ vs. $48.8 \pm$ $6.4 \%$ of DM), but variability was high even within cane molasses (39.2-67.3\% of DM) and beet molasses. Glucose and fructose were detected in cane molasses (5.3 \pm 2.7 and $8.1 \pm 2.8 \%$ of DM, respectively), showing high variability. Organic acid composition differed as well. Lactic acid was more concentrated in cane molasses than in beet molasses $(6.1 \pm 2.8$ vs. $4.5 \pm 1.8 \%$ of $\mathrm{DM})$, varying from 1.6 to $12.8 \%$ of DM in cane molasses. Dietary cation-anion difference showed numerical differences among cane and beet molasses $(7 \pm 53$ vs. $66 \pm$

Received September 25, 2019

Accepted January 20, 2020.

*Present address: DIMEVET, Dipartimento di Scienze Mediche Veterinarie, Università di Bologna, 40064 Ozzano Emilia, Italy.

†Corresponding author: alberto.palmonari2@unibo.it
$45 \mathrm{mEq} / 100 \mathrm{~g}$ of DM, on average). It varied from -76 to $+155 \mathrm{mEq} / 100 \mathrm{~g}$ of $\mathrm{DM}$ in the cane group and from +0 to $+162 \mathrm{mEq} / 100 \mathrm{~g}$ of DM in the beet group. Data obtained in this study detailed differences in composition between sources of molasses and suggested that a more complete characterization could improve the use of molasses in ration formulation.

Key words: molasses, chemical composition, variability

\section{Short Communication}

Beet and cane molasses are produced worldwide as a by-product of sugar extraction and are widely used in animal nutrition. Due to their composition, they are fed to ruminants as an energy source, and interest in their use is still current (Martel et al., 2011; Siverson et al., 2014). Previous studies showed positive effects of molasses addition on milk fat, FCM, ruminal ammonia, MUN, and fiber digestibility (Broderick and Radloff, 2004; Brito et al., 2015; de Ondarza et al., 2017). Addition of molasses could also be associated with nonnutritive and dietetic benefits: animals prefer sweetened diets (Murphy et al., 1997); thus, molasses generally stimulates DMI. Related to this, field observations suggest that molasses or molasses-based liquid feeds could affect animal sorting behavior, with a positive effect on the consumption of longer particles in TMR (DeVries and Gill, 2012). A frequent alternative is to add water whenever the diet is considered too dry (i.e., where hay instead of silage represents the main forage source). During warmer months, however, addition of water could lead to spoilage, thus decreasing the palatability of the diet and causing health problems in the animal. In such conditions, molasses would act positively because it is not associated with spoilage or molds. From a composition standpoint, sugars represent the main component of molasses. Sugars are rapidly fermented in the rumen, but the end products differ from those obtained by starch fermentation (Penner and Oba, 2009). Previous studies indicate that replacing starch 
with molasses or molasses-based liquid feeds would result in positive effects on rumen $\mathrm{pH}$ (Broderick and Radloff, 2004; Oelker et al., 2009; Brito et al., 2017). However, in general, molasses is not properly characterized in the literature, and its description is related to the type (sugarcane or beet) or the amount of DM, total or water-soluble sugars, CP, and ash (Broderick and Radloff, 2004; Brito et al., 2015). Other studies have better described molasses, but the final results still lack in several components, such as organic acids or DCAD (Olbrich, 1963; Bortolussi and O'Neill, 2006). Consequently, a representative part of the DM of molasses remains unknown because sugars, CP, and ash are scarcely sufficient to reach $80 \%$ DM on average.

The objective of this study was to better characterize the composition of cane and beet molasses, underline possible differences, and obtain a proper definition of such feeds. For this purpose, 16 cane and 16 beet molasses samples were sourced worldwide and analyzed for chemical composition. In particular, 7 cane molasses samples were from Central and North America, 5 were from Asia, 2 were from Africa, and 1 each was from $\mathrm{Eu}-$ rope and Australia. Beet molasses was sampled in Europe (12), North America (2), and Africa (2). Dry matter was determined according to AOAC International (1990) official method 934.01, except for dried quartz sand, which was added to each vessel. Ash content was calculated as reported in AOAC International (1990) official method 900.02 for this specific feed. Crude protein determination was carried out following AOAC International (1990) official method 990.03. Starch and other carbohydrates, such as dextran, levan, and araban, were determined with polarimetric procedure 10520:1997(en) (ISO, 1997). For sugar determination, samples were clarified using a commercial kit based on Carrez reagents (Sigma-Aldrich S.r.l, Milan, Italy). After this procedure, glucose, fructose, sucrose, galactose, raffinose, arabinose, and xylose were extracted and quantified using an enzymatic method according to the manufacturer's manual (Megazyme International Ltd., Bray, Ireland). Ash was recovered to quantify Ca, $\mathrm{Mg}, \mathrm{Na}$, and $\mathrm{K}$ with inductively coupled plasma spectrometry, whereas organic acids (lactic, acetic, butyric, propionic, citric, malic, formic, aconitic, glycolic, and oxalic) and other components (sulfates, phosphates, chlorides, and nitrates) were measured using ionic HPLC (Metrohm Italiana Srl, Origgio, Italy) according to methods UNI EN ISO 10304-1 and 14911-1998 (ISO, 1998, 2007).

Statistical analysis was performed using JMP software (version 12.0 Pro, SAS Institute Inc., Cary, NC). Then, a principal component analysis was carried out using the FACTOR procedure of SAS (version 9.13,
SAS Institute Inc.) as described by Gallo et al. (2016). The analysis was conducted to evaluate variability among and across cane or beet molasses.

Overall, determinations of the different components characterized, on average, 97.4 and $98.3 \%$ of the DM in cane and beet molasses, respectively. Analytical results are reported in Tables 1 and 2. Within the cane molasses group, DM ranged from $75.72 \%$ to $79.56 \%$, with an average of $76.8 \%$. An average of $78.3 \% \mathrm{DM}$ was observed in beet molasses, with a minimum of $74.1 \%$ and a maximum of $78.9 \%$. Ash was numerically higher in cane molasses $(13.1 \%$ of DM) than in beet molasses $(11.7 \%$ of DM), with a maximum value of $18.5 \%$ of $\mathrm{DM}$ and a minimum value of $6.5 \%$ of $\mathrm{DM}$ in beet molasses. The CP concentration differed among and within groups, being $6.7 \pm 1.8$ and $13.5 \pm 1.4 \%$ of $\mathrm{DM}$ in cane and beet molasses, respectively, and ranged from a minimum of $2.2 \%$ of $\mathrm{DM}$ in cane molasses to a maximum of $15.6 \%$ of DM in beet molasses. This difference could be related to specific molecules occurring in sugar beet, such as betaine. Betaine, a nitrogen compound that is widely used in the cosmetic, health, and pharmaceutical industries as well as in animal nutrition (Fernández-Fígares et al., 2002; Escudero and Olga Ruiz, 2011), promotes growth and modulates lipid accumulation.

Sugar profile differed among samples. Sucrose was the most represented in both cane and beet molasses, although its concentration varied even within group. In cane molasses, an average of $48.8 \%$ of DM was observed, ranging from $39.2 \%$ to $67.3 \%$. Beet molasses showed a numerically higher sucrose concentration $(60.9 \%$ of DM on average), with a minimum of $46.5 \%$ and a maximum of $66.1 \%$. Glucose and fructose had an average concentration of 8.1 and $5.3 \%$ of DM, respectively, in cane molasses and were barely detectable in beet molasses $(0.3 \%$ of $\mathrm{DM}$ on average for both). The ranges for cane molasses were wide, with maximum values of 14.3 and $12.1 \%$ of DM and minimum values of $2.3 \%$ and $1.3 \%$ of DM for fructose and glucose, respectively. Other analyzed sugars (galactose, raffinose, arabinose, and xylose) were almost undetectable, and even the sum of maximum values was lower than $1 \%$ of $\mathrm{DM}$ in cane molasses. The only exception was raffinose in beet molasses, which was $0.6 \%$ of DM on average, but with a maximum value of $2.2 \%$ of DM. This finding is in line with that observed by Olbrich (2006), who identified sucrose and raffinose as the 2 major sugars in German beet molasses. Reasons for these differences could be related to the extraction process applied as well as the origin of the molasses. Sucrose is a disaccharide that comprises glucose and fructose. Uptakes of these 2 sugars are usually associated, and both represent a major 
Table 1. Descriptive statistics of the chemical composition (\% of DM unless otherwise noted) of cane molasses

\begin{tabular}{|c|c|c|c|c|}
\hline Item & Average & SD & Minimum & Maximum \\
\hline DM & 76.8 & 1.0 & 75.7 & 79.6 \\
\hline $\mathrm{CP}$ & 6.65 & 1.79 & 2.22 & 9.31 \\
\hline Total sugars & 62.3 & 4.7 & 57.0 & 71.0 \\
\hline Sucrose & 48.8 & 6.4 & 39.2 & 67.3 \\
\hline Glucose & 5.29 & 2.69 & 1.30 & 12.07 \\
\hline Fructose & 8.07 & 2.83 & 2.30 & 14.28 \\
\hline Raffinose & 0.03 & 0.00 & 0.02 & 0.03 \\
\hline Galactose & 0.04 & 0.00 & 0.04 & 0.04 \\
\hline Arabinose & 0.01 & 0.02 & 0.00 & 0.04 \\
\hline Xylose & $\mathrm{ND}^{1}$ & $\mathrm{ND}$ & ND & ND \\
\hline Starch & 0.33 & 0.25 & 0.06 & 1.07 \\
\hline Levans & 0.86 & 0.26 & 0.26 & 1.21 \\
\hline Dextrans & 0.79 & 0.42 & 0.27 & 1.63 \\
\hline Arabans & 0.20 & 0.05 & 0.06 & 0.28 \\
\hline Aconitic acid & 1.42 & 0.85 & 0.24 & 3.78 \\
\hline Lactic acid & 6.10 & 2.82 & 1.62 & 12.75 \\
\hline Malic acid & 0.10 & 0.05 & 0.03 & 0.21 \\
\hline Citric acid & 0.13 & 0.04 & 0.08 & 0.22 \\
\hline Pyrocarbonic acid & 0.34 & 0.13 & 0.18 & 0.62 \\
\hline Oxalic acid & 0.06 & 0.02 & 0.04 & 0.09 \\
\hline Glycolic acid & 0.00 & 0.00 & 0.00 & 0.00 \\
\hline Acetic acid & 0.44 & 0.28 & 0.16 & 1.04 \\
\hline Ash & 13.1 & 1.5 & 10.2 & 16.3 \\
\hline $\mathrm{Ca}$ & 1.39 & 0.55 & 0.82 & 3.13 \\
\hline $\mathrm{Mg}$ & 0.43 & 0.14 & 0.19 & 0.63 \\
\hline $\mathrm{Na}$ & 0.08 & 0.10 & 0.01 & 0.42 \\
\hline K & 1.82 & 1.91 & 0.31 & 7.99 \\
\hline Sulfates & 2.09 & 0.88 & 0.81 & 4.09 \\
\hline Sulfur $^{2}$ & 0.69 & 0.29 & 0.27 & 1.36 \\
\hline Phosphates & 2.03 & 0.77 & 0.70 & 2.97 \\
\hline Nitrates, $\mathrm{mg} / \mathrm{kg}$ & 464 & 337 & 17 & 999 \\
\hline Chlorides, mg/kg & 60 & 86 & 1 & 340 \\
\hline $\mathrm{DCAD},{ }^{3} \mathrm{mEq} / 100 \mathrm{~g}$ & 7 & 53 & -76 & 155 \\
\hline
\end{tabular}

substrate for microbial fermentations. However, glucose and fructose could undergo different fermentation pathways (Luick et al., 1957). Thus, considering the variability observed within group (cane or beet), these data suggest that a more accurate analysis is required to properly characterize the molasses.

Differences were also observed in organic acids. Lactic acid was more concentrated in cane molasses than in beet molasses ( 6.1 and $4.5 \%$ of $\mathrm{DM}$, respectively), varying from a minimum of $1.6 \%$ to a maximum of $12.8 \%$ of $\mathrm{DM}$ among cane molasses. Aconitic acid was found only in cane molasses (1.4\% of DM on average), whereas glycolic acid was found in beet molasses $(0.25 \%$ of DM on average). Other analyzed acids (acetic, butyric, propionic, citric, malic, formic, glycolic, and oxalic) were poorly represented in both cane and beet molasses. The total sum of acids ranged from $2.4 \%$ to $18.7 \%$ of $\mathrm{DM}$ in cane molasses, whereas it was a minimum of $4.1 \%$ and a maximum of $11.9 \%$ of DM in beet molasses. Organic acids are not so frequently quantified when molasses is added to a diet. However, considering their variability, such fractions should be determined because organic acids could affect rumen metabolism, leading to different consequences in terms of animal health and performance, as underlined by other authors in respect to silages (Kung et al., 2018).

Starch, dextran, levan, and araban were $2.2 \%$ of DM on average in cane molasses and $<1 \%$ of $\mathrm{DM}$ in beet molasses. Due to the low concentration, the variability range was also narrow. Sulfates, phosphates, and chlorides had a higher concentration in cane molasses, which showed a numerically lower DCAD compared with beet molasses $(7 \pm 53$ vs. $66 \pm 45 \mathrm{mEq} / 100 \mathrm{~g}$ of $\mathrm{DM})$. Within the cane group, DCAD varied from -76 to $+155 \mathrm{mEq} / 100 \mathrm{~g}$ of $\mathrm{DM}$ in the cane group and from 0 to $+162 \mathrm{mEq} / 100 \mathrm{~g}$ of $\mathrm{DM}$ in the beet group. The observed DCAD variability across samples underlines the importance of this determination when molasses is added to the diet. Even with a similar amount of total sugars, different molasses types could have a completely 
Table 2. Descriptive statistic of the chemical composition (\% of DM unless otherwise noted) of beet molasses

\begin{tabular}{|c|c|c|c|c|}
\hline Item & Average & $\mathrm{SD}$ & Minimum & Maximum \\
\hline DM & 77.6 & 3.2 & 67.0 & 80.9 \\
\hline $\mathrm{CP}$ & 13.5 & 1.4 & 10.7 & 15.6 \\
\hline Total sugars & 62.1 & 3.9 & 50.6 & 68.4 \\
\hline Sucrose & 60.9 & 4.4 & 46.5 & 66.1 \\
\hline Glucose & 0.28 & 0.48 & 0.02 & 1.96 \\
\hline Fructose & 0.29 & 0.30 & 0.01 & 0.87 \\
\hline Raffinose & 0.60 & 0.56 & 0.12 & 2.18 \\
\hline Galactose & 0.03 & 0.00 & 0.02 & 0.03 \\
\hline Arabinose & 0.01 & 0.01 & 0.00 & 0.05 \\
\hline Xylose & 0.01 & 0.00 & 0.00 & 0.01 \\
\hline Starch & 0.08 & 0.04 & 0.02 & 0.17 \\
\hline Levans & 0.47 & 0.16 & 0.15 & 0.71 \\
\hline Dextrans & 0.09 & 0.04 & 0.02 & 0.19 \\
\hline Arabans & 0.06 & 0.02 & 0.03 & 0.10 \\
\hline Aconitic acid & $\mathrm{ND}^{1}$ & ND & ND & ND \\
\hline Lactic acid & 4.51 & 1.83 & 1.77 & 7.13 \\
\hline Malic acid & 0.08 & 0.04 & 0.02 & 0.13 \\
\hline Citric acid & 0.30 & 0.12 & 0.11 & 0.50 \\
\hline Pyrocarbonic acid & 2.77 & 0.52 & 1.74 & 3.76 \\
\hline Oxalic acid & 0.03 & 0.01 & 0.02 & 0.05 \\
\hline Glycolic acid & 0.25 & 0.04 & 0.18 & 0.32 \\
\hline Acetic acid & 0.42 & 0.12 & 0.20 & 0.60 \\
\hline Ash & 11.7 & 2.5 & 6.5 & 18.5 \\
\hline $\mathrm{Ca}$ & 0.30 & 0.35 & 0.02 & 1.24 \\
\hline $\mathrm{Mg}$ & 0.02 & 0.02 & 0.00 & 0.09 \\
\hline $\mathrm{Na}$ & 0.62 & 0.43 & 0.05 & 1.45 \\
\hline K & 2.44 & 1.33 & 0.65 & 5.54 \\
\hline Sulfates & 0.61 & 0.41 & 0.17 & 1.84 \\
\hline Sulfur $^{2}$ & 0.20 & 0.14 & 0.06 & 0.61 \\
\hline Phosphates & 0.76 & 0.38 & 0.31 & 1.65 \\
\hline Nitrates, $\mathrm{mg} / \mathrm{kg}$ & 55 & 29 & 16 & 116 \\
\hline Chlorides, mg/kg & 3,974 & 2,236 & 411 & 8,056 \\
\hline $\mathrm{DCAD},{ }^{3} \mathrm{mEq} / 100 \mathrm{~g}$ & 66 & 45 & 0 & 162 \\
\hline
\end{tabular}

different anion:cation ratio, with possible effects on animal health and performance. For example, given a ration for close-up cows (270 d of pregnancy) formulated with corn silage, grass hay, corn meal, soybean meal, and a mineral-vitamin supplement, such ration would result in a DCAD of $\sim 39 \mathrm{mEq} / 100 \mathrm{~g}$. Substituting corn meal with the molasses at opposite values $(-76$ and $+155 \mathrm{mEq} / 100 \mathrm{~g}$ ), the final DCAD would be +38 and $+48 \mathrm{mEq} / 100 \mathrm{~g}$. As reported in the literature, a proper balance is required to avoid the occurrence of disease in different stages of lactation (Block, 1994; Goff and Horst, 1997; Hu and Murphy, 2004) or in animals under stressful environmental conditions (West et al., 1991, 1992; Sanchez et al., 1994).

Sample distribution resulting from the principal component analysis is reported in Figure 1. Range of variability was wide among the samples and even within the same group, especially in cane molasses. In conclusion, the obtained results demonstrate that differences in composition could occur among molasses.
Defining a molasses as cane or beet is important but not sufficient to properly evaluate its potential nutritional role. As reported in several studies in which molasses was added to the diets, determination of ash, $\mathrm{CP}$, total sugars, and few other components represents partial identification and does not seem appropriate for characterizing such feeds. Molasses is a good source of fermentable sugars, but other components are present as well, with potential effects on animal health status or production performance. Moreover, from a scientific standpoint, use of molasses, which can be similar in terms of amount of total sugars or protein but different in organic acids or in minerals, could lead to different results across studies, as observed by other authors (Firkins et al., 2008; Baurhoo and Mustafa, 2014; Ghedini et al., 2018). Thus, this study underlines that a more accurate description and characterization of molasses is possible and strictly required, especially if its use in animal feed has to be fully optimized. 


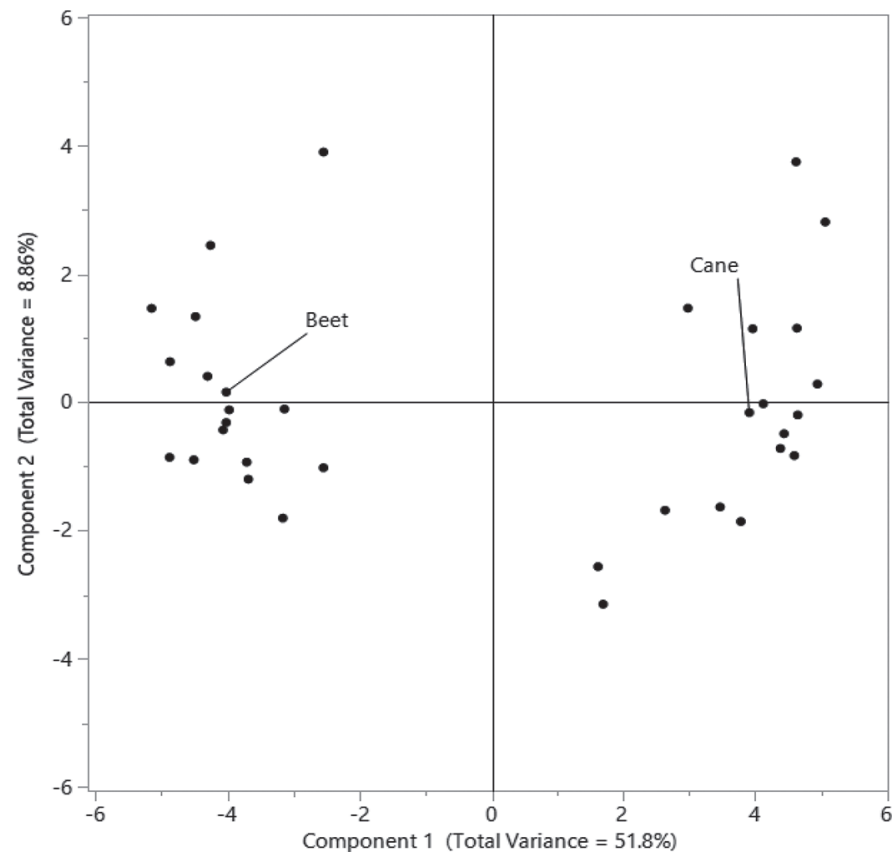

Figure 1. Samples distribution. Principal component analysis results for molasses variability. Distance between dots is inversely proportional to the similarity among samples.

\section{ACKNOWLEDGMENTS}

The authors acknowledge ED\&F Man Liquid Products, London, UK, for supporting the study. The authors confirm that they have no conflicts of interest.

\section{REFERENCES}

AOAC International. 1990. Official Methods of Analysis. 15th ed. Vol. 1. AOAC International, Gaithersburg, MD.

Baurhoo, B., and A. Mustafa. 2014. Short communication: Effect of molasses supplementation on performance of lactating cows fed high-alfalfa silage diets. J. Dairy Sci. 97:1072-1076. https://doi .org/10.3168/jds.2013-6989.

Block, E. 1994. Manipulation of dietary cation-anion difference on nutritionally related production diseases, productivity, and metabolic responses of dairy cows. J. Dairy Sci. 77:1437-1450. https://doi .org/10.3168/jds.S0022-0302(94)77082-X.

Bortolussi, G., and C. J. O'Neill. 2006. Variation in molasses composition from eastern Australian sugar mills. Aust. J. Exp. Agric. 46:1455-1463. https://doi.org/10.1071/EA04124.

Brito, A. F., H. V. Petit, A. B. D. Pereira, K. J. Soder, and S. Ross. 2015. Interactions of corn meal or molasses with a soybean-sunflower meal mix or flaxseed meal on production, milk fatty acid composition, and nutrient utilization in dairy cows fed grass haybased diets. J. Dairy Sci. 98:443-457. https://doi.org/10.3168/jds 2014-8353.

Brito, A. F., K. J. Soder, P. Y. Chouinard, S. F. Reis, S. Ross, M. D. Rubano, and M. D. Casler. 2017. Production performance and milk fatty acid profile in grazing dairy cows offered ground corn or liquid molasses as the sole supplemental nonstructural carbohydrate source. J. Dairy Sci. 100:8146-8160. https://doi.org/10 $.3168 /$ jds.2017-12618

Broderick, G. A., and W. J. Radloff. 2004. Effects of molasses supplementation on the production of lactating dairy cows fed diets based on alfalfa and corn silage. J. Dairy Sci. 87:2997-3009. https: //doi.org/10.3168/jds.S0022-0302(04)73431-1.

de Ondarza, M. B., S. M. Emanuele, and C. J. Sniffen. 2017. Effect of increased dietary sugar on dairy cow performance as influenced by diet nutrient components and level of milk production. Prof Anim. Sci. 33:700-707. https://doi.org/10.15232/pas.2017-01648.

DeVries, T. J., and R. M. Gill. 2012. Adding liquid feed to a total mixed ration reduces feed sorting behavior and improves productivity of lactating dairy cows. J. Dairy Sci. 95:2648-2655. https:/ doi.org/10.3168/jds.2011-4965.

Escudero, I., and M. Olga Ruiz. 2011. Extraction of betaine from beet molasses using membrane contactors. J. Membr. Sci. 372:258-268. https://doi.org/10.1016/j.memsci.2011.02.008.

Fernández-Fígares, I., D. Wray-Cahen, N. C. Steele, R. G. Campbell, D. D. Hall, E. Virtanen, and T. J. Caperna. 2002. Effect of dietary betaine on nutrient utilization and partitioning in the young growing feed-restricted pig. J. Anim. Sci. 80:421-428. https://doi.org/ $10.2527 / 2002.802421 x$.

Firkins, J. L., B. S. Oldick, J. Pantoja, C. Reveneau, L. E. Gilligan, and L. Carver. 2008. Efficacy of liquid feeds varying in concentration and composition of fat, nonprotein nitrogen, and nonfiber carbohydrates for lactating dairy cows. J. Dairy Sci. 91:1969-1984. https://doi.org/10.3168/jds.2007-0868.

Gallo, A., T. Bertuzzi, G. Giuberti, M. Moschini, S. Bruschi, C. Cerioli, and F. Masoero. 2016. New assessment based on the use of principal factor analysis to investigate corn silage quality from nutritional traits, fermentation end products and mycotoxins. J. Sci. Food Agric. https://doi.org/10.1002/jsfa.7109.

Ghedini, C. P., D. C. Moura, R. A. V. Santana, A. S. Oliveira, and A. F. Brito. 2018. Replacing ground corn with incremental amounts of liquid molasses does not change milk enterolactone but decreases production in dairy cows fed flaxseed meal. J. Dairy Sci. 101:2096-2109. https://doi.org/10.3168/jds.2017-13689.

Goff, J. P., and R. L. Horst. 1997. Effects of the addition of potassium or sodium, but not calcium, to prepartum rations on milk fever in dairy cows. J. Dairy Sci. 80:176-186. https://doi.org/10.3168/jds .S0022-0302(97)75925-3.

Hu, W., and M. R. Murphy. 2004. Dietary cation-anion difference effects on performance and acid-base status of lactating dairy cows: A meta-analysis. J. Dairy Sci. 87:2222-2229. https://doi.org/10 .3168/jds.S0022-0302(04)70042-9.

ISO (International Organization for Standardization). 1997. Native starch-Determination of starch content-Ewers polarimetric method. Standard number 10520:1997(en). ISO, Geneva, Switzerland.

ISO (International Organization for Standardization). 1998. Water quality-Determination of dissolved $\mathrm{Li}+, \mathrm{Na}+, \mathrm{NH} 4+, \mathrm{K}+$, $\mathrm{Mn} 2+, \mathrm{Ca} 2+, \mathrm{Mg} 2+, \mathrm{Sr} 2+$ and $\mathrm{Ba} 2+$ using ion chromatographyMethod for water and waste water. Standard number 14911:1998 ISO, Geneva, Switzerland.

ISO. (International Organization for Standardization). 2007. Water quality - Determination of dissolved anions by liquid chromatography of ions. Standard number 10304-1. ISO, Geneva, Switzerland

Kung. L. Jr., R. D. Shaver, R. J. Grant, and R. J. Schmidt. 2018. Silage review: Interpretation of chemical, microbial, and organoleptic components of silages. J. Dairy Sci. 101:4020-4033. https:// doi.org/10.3168/jds.2017-13909.

Luick, J. R., M. Kleiber, J. M. Lucas, and T. A. Rogers. 1957. Fructose metabolism in dairy cows. Am. J. Physiol. 191:90-94. https://doi .org/10.1152/ajplegacy.1957.191.1.90.

Martel, C. A., E. C. Titgemeyer, L. K. Mamedova, and B. J. Bradford. 2011. Dietary molasses increases ruminal $\mathrm{pH}$ and enhances ruminal biohydrogenation during milk fat depression. J. Dairy Sci. 94:3995-4004. https://doi.org/10.3168/jds.2011-4178.

Murphy, M. R., A. W. P. Geijsel, E. C. Hall, and R. D. Shanks. 1997. Dietary variety via sweetening and voluntary feed intake by lactating dairy cows. J. Dairy Sci. 80:894-897. https://doi.org/10.3168/ jds.S0022-0302(97)76011-9.

Oelker, E. R., C. Reveneau, and J. L. Firkins. 2009. Interaction of molasses and monensin in alfalfa hay- or corn silage-based diets on rumen fermentation, total tract digestibility, and milk produc- 
tion by Holstein cows. J. Dairy Sci. 92:270-285. https://doi.org/ $10.3168 /$ jds.2008-1432.

Olbrich, H. 1963. The molasses. Accessed Jan. 20, 2020. http://www .btkempe.de/Molasses_OLBRICH.pdf.

Penner, G. B., and M. Oba. 2009. Increasing dietary sugar concentration may improve dry matter intake, ruminal fermentation, and productivity of dairy cows in the postpartum phase of the transition period. J. Dairy Sci. 92:3341-3353. https://doi.org/10.3168/ jds.2008-1977.

Sanchez, W. K., M. A. McGuire, and D. K. Beede. 1994. Macro mineral nutrition by heat stress interactions in dairy cattle: Review and original research. J. Dairy Sci. 77:2051-2079. https://doi.org/ 10.3168/jds.S0022-0302(94)77150-2.

Siverson, A., C. F. Vargas-Rodriguez, and B. J. Bradford. 2014. Short communication: Effects of molasses products on productivity and milk fatty acid profile of cows fed diets high in dried distillers grains with solubles. J. Dairy Sci. 97:3860-3865. https://doi.org/ 10.3168/jds.2014-7902.

West, J. W., K. D. Haydon, B. G. Mullinix, and T. G. Sandifer. 1992. Dietary cation-anion balance and cation source effects on pro- duction and acid-base status of heat-stressed cows. J. Dairy Sci. 75:2776-2786. https://doi.org/10.3168/jds.S0022-0302(92)78041 -2 .

West, J. W., B. G. Mullinix, and T. G. Sandifer. 1991. Changing dietary electrolyte balance for dairy cows in cool and hot environments. J. Dairy Sci. 74:1662-1674. https://doi.org/10.3168/jds .S0022-0302(91)78329-X.

\section{ORCIDS}

A. Palmonari @ https://orcid.org/0000-0003-3735-8826

C. J. Sniffen ำ https://orcid.org/0000-0003-3932-8364

P. Holder ๑ https://orcid.org/0000-0001-7394-668X

I. Fusaro @ https://orcid.org/0000-0002-2532-7240

A. Formigoni (i) https://orcid.org/0000-0002-8109-2482

L. Mammi $\odot$ https://orcid.org/0000-0002-7344-0686 